\title{
PROROTIPE ALARM PANIC BUTTON SYSTEM PADA WILAYAH HUKUM POLRES KOTA TANGERANG
}

\author{
Ahmad Roihan', Annas Rifa'i ${ }^{2}$, Chandra Wijaya ${ }^{3}$ \\ ${ }^{1}$ Dosen STMIK Raharja Tangerang, ${ }^{2,3}$ Mahasiswa STMIK Raharja Tangerang \\ E-mail: ${ }^{1}$ ahmad.roihan@ raharja.info, ${ }^{2}$ annas.rifai@ raharja.info, ${ }^{3}$ chandra@ raharja.info
}

\begin{abstract}
Abstrak
Perkembangan teknologi informatika menawarkan institusi berupa kemudahan dalam menyediakan sebuah solusi baru sebagai alat bantu yang baik bagi perbaikan sistem yang kurang ideal. SPKT (Sentral Pelayanan Kepolisian Terpadu) merupakan tempat pelayanan pengaduan masyarakat perihal bantuan dari pihak kepolisian ketika terjadi tindak kejahatan atau kriminalisasi. Perlu adanya inovasi dalam sistem pelayanan laporan masyarakat kepada Polres Kota Tangerang agar lebih efektif atau efesien. Dalam mengatasi masalah tersebut Alarm Panic Button System dapat memberikan kemudahan untuk menghubungi pihak kepolisian ketika terjadi tindak kejahatan. Perancangan alat dimulai dengan membuat prototipe alat berupa mikrokontroler yang terdiri dari beberapa komponen. Kemudian mikrokontroler dirakit dan dimasukkan program dengan menggunakan software Arduino1.8.1 yang dihubungkan dengan Modul SIM 800L sebagai pusat rangkaian untuk mengirimkan pesan. Pesan tersebut akan dikirim langsung kepada Polres Kota Tangerang. Tujuan dari penelitian dapat memberikan pelayanan lebih cepat dengan sebuah akses untuk memudahkan masyarakat dalam memberitahukan dan melaporkan tindak pidana kejahatan atau yang lainnya kepada pihak kepolisian tentang kejadian yang terjadi di tempat kerja, rumah ataupun pertokoan. Sehingga pihak kepolisian mampu mengetahui lebih awal mengenai kejadian yang terjadi dan kemudian mengambil tindakan preventif untuk mengatasinya.
\end{abstract}

Kata Kunci-Bel Listrik, Arduino Uno, SIM 800L, Smartphone

\begin{abstract}
The development of informatics technology offers organizations the ease of providing a new solution for the improvement of the less ideal system. SPKT (Sentral Pelayanan Kepolisian Terpadu) is the place of public complaints service regarding assistance from the police when there is a crime or criminalization, report etc. It needs innovation in public service report system to Polresta Tangerang to be more effective or efficient. In overcoming the problem Alarm Panic Button System can provide convenience to contact the Police when there is a crime. The design of the tool begins by creating a prototype tool with a circuit consisting of several components. Then the tool assembled and embedded the script by using software Arduino Uno v3.0 which is connected with SIM Module 800L GPRS GSM Micro Sim as the part of the circuit to send the message. The message will be sent directly to Polresta Tangerang. The purpose of the study can be to provide services with an access to facilitate the public in informing and reporting criminal or other crimes to the police about events occurring at work, home or market. So the police are able to find out earlier about the incident and then take quick action to overcome it.
\end{abstract}

Keywords - Electric Bell, Arduino Uno, SIM 800L, Smartphone

\section{PENDAHULUAN}

Pada dasarnya manusia tidak bisa memprediksi kapan datangnya bahaya yang bisa mengancam atau bahkan mengambil nyawa seseorang. Bahaya tersebut bisa terjadi karena disebabkan oleh manusia ataupun alam. Oleh karena itu, setiap manusia menginginkan situasi keamanan yang selalu kondusif, berbagai cara dapat dilakukan untuk keamanan pada suatu tempat atau daerah. 
Polres Kota Tangerang merupakan instansi kepolisian yang bertugas untuk melayani, mengayomi dan melindungi masyarakat. Sebagai salah satu tim dari Anggota Seksi Pengawasan di Polres Kota Tangerang bermaksud ingin memberikan pelayanan berbasis teknologi yang berjalan meliputi semua aspek tidak hanya pelayanan tetapi keamanan bagi masyarakat. Pekerjaan tanpa sistem dan teknologi dapat menjadi sebuah hambatan bagi ruang lingkup suatu organisasi atau instansi karena masih menggunakan sistem manual.

Sesuai dalam Undang-Undang Dasar 1945 Pasal 30 ayat (4), Kepolisian Negara Republik Indonesia atau sering disingkat dengan Polri merupakan alat Negara yang berperan dalam memelihara keamanan dan ketertiban masyarakat, menegakan hukum serta memberikan perlindungan, pengayoman dan pelayanan kepada masyarakat dalam rangka terpeliharanya keamanan dalam negeri.

Polri juga memiliki peranan penting dalam memberikan pelayanan kepada masyarakat dalam mengurus hal-hal yang berkaitan dengan tindak pidana. Sentra Pelayanan Kepolisian Terpadu atau disingkat SPKT adalah tempat yang memfasilitasi bidang pelayanan yang menyangkut pelayanan masyarakat dalam bentuk penerimaan laporan dan penanganan pertama laporan serta pengaduan dari masyarakat, penyajian informasi publik umumnya berkaitan dengan kepentingan masyarakat sesuai dengan ketentuan peraturan Perundang-Undangan. SPKT bertugas memberikan pelayanan kepolisian kepada masyarakat, dalam bentuk penerimaan dan penanganan pertama laporan atau pengaduan, pelayanan bantuan atau pertolongan kepolisian, bersama fungsi terkait mendatangi TKP untuk melaksanakan kegiatan pengamanan dan olah TKP sesuai ketentuan hukum dan peraturan yang berlaku[1].

Pemberlakuan Undang-Undang Republik Indonesia Nomor 14 tahun 2008 tentang Keterbukaan Informasi Publik yang diberlakukan mulai 30 April 2010 merupakan momentum penting dalam mendorong keterbukaan informasi publik pada seluruh Instansi dan Lembaga di Indonesia, khususnya di Instansi Kepolisian Republik Indonesia (POLRI). Undang-Undang ini telah memberikan landasan hukum terhadap hak setiap orang yang memperoleh informasi publik dimana setiap Badan Publik mempunyai kewajiban dalam menyediakan dan melayani permohonan publik secara cepat, tepat waktu, biaya ringan dan cara sederhana.

Dengan adanya pedoman ini keresahan masyarakat apabila terjadi tindak pidana kejahatan akan menjadi aman, maka Polri adalah bagian dari masyarakat yang setiap saat hadir di tengah-tengah masyarakat apabila masyarakat sedang memerlukan bantuan. Saat ini, cara untuk menghubungi pihak Kepolisian atau Instansi terkait umumnya yang pertama kali dilakukan adalah menelpon 110 atau mendatangi kantor kepolisian. Cara itu dirasakan masih kurang efektif untuk menjaga rasa aman dalam pelayanan kepada masyarakat. Oleh karena itu, sistem komputerisasi pada teknologi begitu menduduki peran sentral untuk mendukung seluruh aktivitas organisasi atau instansi terhadap suatu pekerjaan setiap manusia.

Alarm adalah sebuah bunyi peringatan atau pemberitahuan dalam hal apapun termasuk ketika terjadi bahaya dan merupakan salah satu cara yang paling banyak diminati untuk memantau keamanan saat terjadi bahaya. Namun bukan berarti alarm bukan tanpa masalah, permasalahan pada alarm yaitu biasanya terjadi pada perancangan sampai pengujian. Permasalahan ini harus dapat dipecahkan dengan melihat proses pembuatan, instalasi, gejala kerusakan yang akan terjadi dan pengujiaan atau implementasi dengan efektif dan efisien.

Adapun masalah yang terjadi selama ini yaitu pada saat proses pelayanan pengaduan informasi publik dengan sistem yang sudah berjalan saat ini di Polres Kota Tangerang masih kurang efektif dan efisien. Ketika terdapat masyarakat yang ingin membutuhkan bantuan polisi dalam situasi mendesak atau sedang terjadinya tindak kejahatan seperti perampokan, pemohon hanya bisa menghubungi ke Sentral Pelayanan Kepolisian Terpadu (SPKT) Polres Kota Tangerang. Proses penerimaan informasi yang memakan waktu, dapat terjadi lambatnya penindakan terhadap tindak kejahatan dan mempengaruhi dalam sistem pelayanan kepolisian yang kurang efektif.

Tujuan dari prototipe Alarm Panic Button System yaitu alat ini dapat difungsikan sebagai penunjang tugas Polri dalam penerapan pelayanan yang maksimal dan untuk memudahkan masyarakat dalam pelaporan tentang adanya tindak kejahatan serta peningkatan produktivitas anggota Polri dalam bekerja. Serta sebagai bentuk tanggung jawab instansi Polri terhadap lingkungan dan tugas Polri sebagai pelindung, pengayom dan pelayan kepada masyarakat.

Berdasarkan masalah yang ada dalam penelitian ini, dapat memberikan alternatif pemecahan masalah yaitu dengan cara merancang sebuah alat pelayanan informasi publik untuk memudahkan 
masyarakat dalam mengatasi adanya tindak kejahatan, baik di lingkungan kerja ataupun sekitarnya. Selain mudah dioperasikan, alat ini dapat memberikan pelayanan yang lebih efektif dan efesien.

Penelitian ini merupakan pengembangan dari beberapa penelitian sebelumnya yang terkait, kemudian objek penelitian dibatasi hanya dalam wilayah hukum Polres Kota Tangerang. Penelitian yang dilakukan saat ini yaitu terkait dengan perancangan prototipe Alarm Panic Button System.

\section{METODE PENELITIAN}

Dalam menyelesaikan perancangan prototipe ini, maka dilaksanakanlah sebuah penelitian sehingga dapat memperoleh dan mencapai suatu hasil akhir sesuai dengan keinginan yang diharapkan. Adapun metodologi yang digunakan dalam penelitian yaitu,

a. Metode Pengumpulan Data

Observasi dilakukan dan menghasilkan pelayanan yang lebih optimal dan ingin memudahkan masyarakat apabila sedang membutuhkan bantuan kepada pihak Kepolisian untuk menjaga keamanan dan ketertiban masyarakat serta memaksimalkan teknologi yang ada di era modern ini. Peneliti melakukan rangkaian proses tanya-jawab kepada pihak untuk lebih mengetahui kondisi dan permasalahan yang ada, tepatnya dari segi keamanan sistemnya.

Pada metode kajian pustaka digunakan untuk mengumpulkan informasi dengan mencatat dan mempelajari buku-buku yang berkaitan sesuai dengan penelitian untuk mencari dan mendapatkan berbagai sumber-sumber kajian. Sumber lainnya dari pencarian situs internet atau mengumpulkan data dari informasi langsung di Sentra Pelayanan Kepolisian Terpadu pada Polres Kota Tangerang yang dapat mendukung dalam suatu penelitian yang berkaitan dengan penelitian baik perencanaan, percobaan, pembuatan, penyusunan laporan.

b. Metode Analisa

Pada metode ini peneliti menganalisa dari sistem-sistem yang sudah ada dengan membuat beberapa poin pertimbangan seperti bagaimana sistem dapat bekerja (cara kerja sistem), apa saja komponen yang membangun sebuah sistem dapat berjalan dan apa kekurangan pada sistem tersebut.

c. Metode Perancangan

Pada metode ini peneliti dapat mengetahui bagaimana sistem dirancang dan komponen apa saja yang dibutuhkan untuk membangun sistem ini. Metode ini dimaksudkan untuk menghasilkan suatu rangkaian alat yang tepat sehingga diperoleh hasil rancangan yang sesuai dengan yang diinginkan[2]. Metode perancangan yang dipakai dalam penelitian ini diawali dengan pembuatan flowchart cara kerja alat. Lalu pembuatan diagram blok dari alat yang dirancang. Tujuan dari metode ini untuk mengetahui komponen apa saja yang diperlukan dan bagaimana gambaran alat secara keseluruhan.

Kerangka berpikir merupakan bagian dari penelitian yang menggambarkan alur pikiran peneliti. Kerangka berpikir merupakan model konseptual tentang bagaimana teori berhubungan dengan berbagai faktor yang telah didefinisikan sebagai masalah yang penting. Kerangka berpikir dapat berupa kerangka teori dan dapat pula berbentuk kerangka penalaran logis. Kerangka teori itu merupakan uraian ringkas tentang teori yang digunakan dan cara menggunakan teori itu dalam menjawab pertanyaan penelitian. Kerangka berpikir itu bersifat operasional, yang diturunkan dari satu atau beberapa teori atau dari pernyataan-pernyataan yang logis dan berhubungan dengan masalah penelitian. 


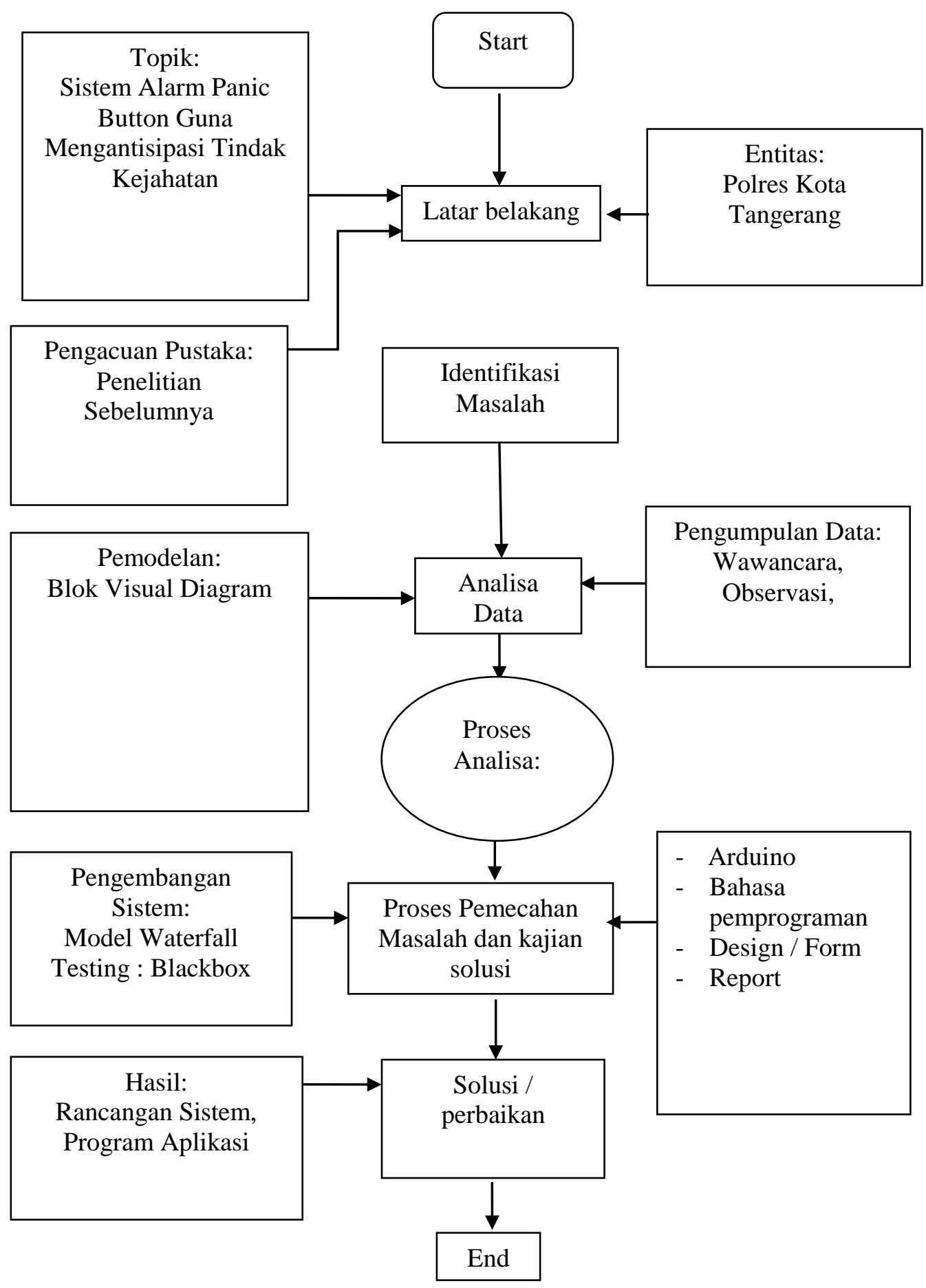

Gambar 1. Kerangka Berpikir

Pada bagian ini diuraikan landasan substantif dalam arti teoritis yang dipergunakan peneliti dalam menentukan alternatif yang akan diimplementasikan. Untuk keperluan itu, dalam bagian ini diuraikan kajian baik pengalaman peneliti atau pelaku penelitian tindakan lain sendiri yang relevan disamping teori-teori yang lazim termuat dalam berbagai kepustakaan. Argumentasi logis dan teoretis diperlukan guna menyusun kerangka konseptual. Atas kerangka konseptual yang disusun itu, hipotesis tindakan dirumuskan.

Pada tahap latar belakang dijelaskan mengenai latar belakang masalah yang terjadi di Polres Kota Tangerang, dan juga topik yang dibahas oleh peneliti mengenai sistem pelayanan yang lebih optimal kepada masyarakat guna mengantisipasi tindak kejahatan dengan menggunakan kajian pustaka yang berasal dari penelitian sebelumnya. Kemudian tahapan identifikasi masalah peneliti membuat kesimpulan berdasarkan dari latar belakang yang telah dijelaskan sebelumnya. Tahapan 
selanjutnya yaitu analisa data, yang mana peneliti melakukan analisa data berdasarkan informasi yang didapatkan dari wawancara serta observasi di lapangan. Proses analisa dilakukan berdasarkan dari hasil yang diperoleh pada saat analisa data, semua data yang diperoleh pada saat dilakukannya analisa data dikumpulkan untuk kemudian dilakukan proses analisa. Proses pemecahan masalah dengan melakukan perancangan hardware dan software dengan bahasa pemrograman yang sesuai dengan alat yang digunakan. Setelah masalah pada Polres Kota Tangerang telah diketahui, maka selanjutnya peneliti mencari solusi dari masalah yang ada, untuk kemudian melakukan perbaikan untuk mengatasi masalah tersebut, dengan merancang Alarm Panic Button dengan mikrokontroler dan perangkat lainnya yang selanjutnya terintegrasi menggunakan bahasa program.

Pengacuan pustaka terdiri dari beberapa penelitian telah dilakukan terkait dengan penelitian ini, diantaranya dilakukan oleh Priyanka Shinde, Pranita Taware, Snehal Thorat, Tejashree Waghmare BE yang merupakan bimbingan dari Prof. Archana Kadam yang membahas tentang Emergency Panic Button[3].

Penelitian sebelumnya juga dilakukan oleh Nivedita Majumdar, Pragati Bhargava, Rubeena K Shirin tentang Emergency Panic Button using Microcontrollers[4]. Penelitian yang terkait lainnya oleh Oludele Awodele, Onuiri Ernest E., Olaore Olufunmike A., Sowunmi Oluwawunmi O, UgoEzeaba Anita A penelitian ini membahas tentang A Real-Time Crime Records Managements System For National Security Agencies[5].

\section{HASIL DAN PEMBAHASAN}

Pada langkah-langkah perancangan ini pertama kali yang dilakukan yaitu pembuatan desain prototipe alat untuk menggambarkan penempatan rangkaian yang akan dibuat menggunakan software aplikasi fritzing, kemudian perakitan alat yang telah digambarkan dibuat prototipe, setelah itu pengkodean dilakukan untuk menanam instruksi ke dalam perangkat mikrokontroler[6] yaitu Arduino Uno. Pengkodean alat dilakukan dengan menggunakan software Arduino 1.8.1 yang dihubungkan dengan Modul SIM 800L GPRS GSM Micro Sim sebagai pusat rangkaian untuk mengirimkan pesan. Setelah itu peneliti melakukan uji coba berbagai fungsi yang ditanamkan pada alat dan melakukan peninjauan ulang atas pengujian tersebut dalam rangka perbaikan.

Flowchart berfungsi sebagai gambaran proses atau langkah-langkah sistematis yang digunakan dalam pemecahan masalah dengan menggunakan berbagai macam simbol dan keterangan singkat dari proses yang berjalan. Gambar 2 berikut merupakan flowchart yang peneliti gunakan dalam perancangan prototipe dalam penelitian ini. 


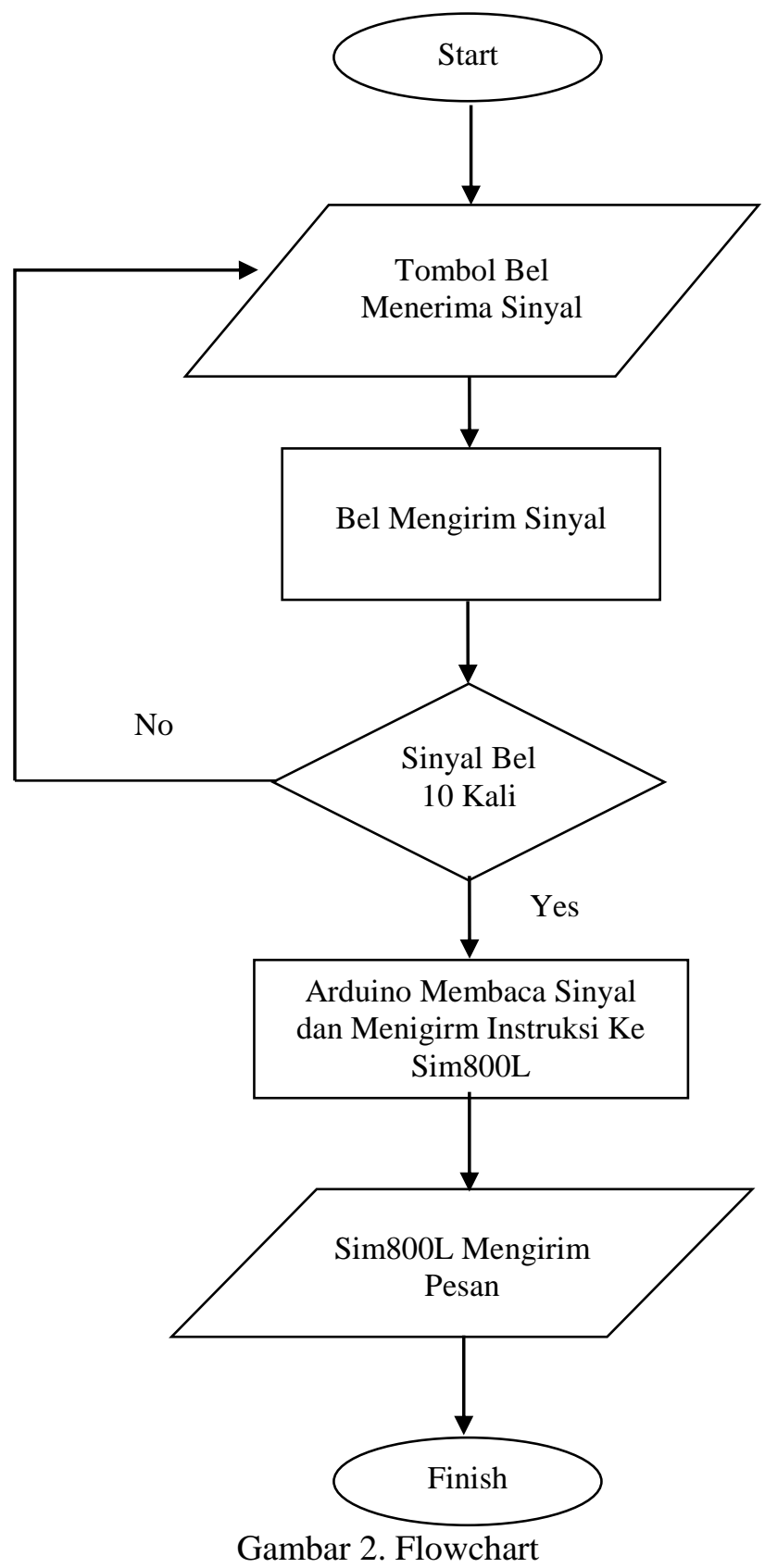

Gambar 3 berikut merupakan blok visual diagram yang terdiri dari perancangan alat, realisasi sistem, dan pengujian. Secara prinsip alat menggunakan Arduino sebagai pengendali alat. 


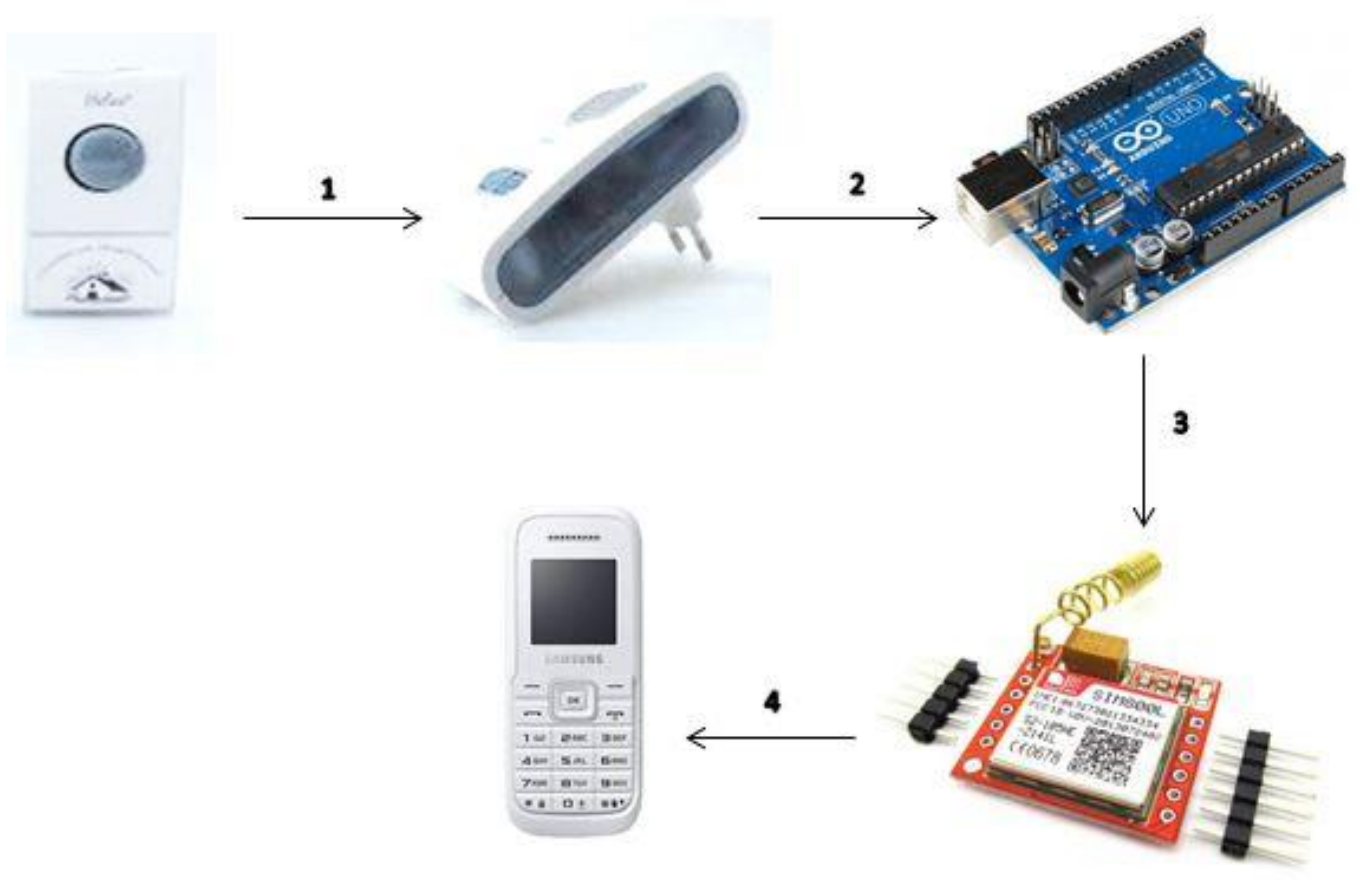

Gambar 3. Blok Visual Diagram

Cara kerja alat yang pertama yaitu tombol bel sebagai sumber untuk mengirimkan sinyal kepada receiver. Kemudian receiver menerima sinyal dari tombol bel dan LED akan berkedip pada receiver selama 10 kali. Setelah itu arduino menangkap sinyal pada receiver melalui Pin 4 . Kemudian arduino juga secara otomatis mengirim sinyal ke SIM 800L untuk diteruskan ke handphone dalam format pesan SMS. Handphone menerima pesan SMS dari SIM 800L ke nomor yang sudah di atur sebelumnya.

Dalam perancangan alat ini peneliti menggunakan berbagai macam komponen perangkat keras (hardware) dan perangkat lunak (software) yang dibutuhkan untuk mencapai tujuan perancangan alat.

Perancangan perangkat keras adalah penentuan rangkaian yang akan digunakan saat pembuatan alat, berikut komponen-komponen yang dipakai dalam perancangan alat:

a. Arduino Uno

Arduino Uno adalah salah satu varian dari produk mikrokontroler keluaran Arduino. Dengan ukuran board yang tidak besar, arduino ini menggunakan mikrokontroler Atmega 328. Arduino Uno tidak dilengkapi dengan soket catu daya, tetapi terdapat pin untuk catu daya luar atau dapat menggunakan catu daya dari mini USB port, Arduino Uno juga dapat dengan mudah diberikan program dengan menggunakan software Arduino IDE dan juga Arduino tipe ini sudah dilengkapi dengan program boatloader, sehingga programmer dapat langsung mengunggah kode program langsung ke dalam board Arduino Uno tanpa melalui board perantara atau hardware lain.

b. Modul SIM 800L

SIM800L adalah modul GSM yang dapat mengakses GPRS yang berfungsi sebagai pengirim data ke internet dengan sistem M2M. AT-Command pada modul ini serupa dengan modul-modul GSM sebelumnya. Sehingga jika diinginkan, modul ini dapat diganti dengan modul GSM lain yang mempunyai komunikasi data serial TTL sebagai interface dengan mikrokontroler. SIM800L memiliki dimensi yang kecil sehingga lebih cocok untuk diaplikasikan pada perancangan alat yang didesain portable. Sim 800L memiliki Quad Band 850 / 900 / 1800 / 1900 Mhz dengan dimensi kecil yaitu ukuran $15.8 \times 17.8 \times 2.4 \mathrm{~mm}$ dan berat $1.35 \mathrm{~g}$. SIM $800 \mathrm{~L}$ memiliki konsumsi daya yang rendah dengan rentang tegangan power supply $3.4-4.4 \mathrm{v}$.

c. Bel Listrik

Bel listrik ini merupakan suatu alat yang penting dalam setiap rumah ataupun perusahaan, bel listrik dalam penelititan ini menggunakan versi tanpa kabel(wireless) sehingga dapat memudahkan untuk menggunakannya. 


\section{d. Handphone}

Pelaksanaan monitoring menggunakan handphone sebagai media penerima pesan dari SIM800L dengan notifikasi data yang terkirim.

Selain penggunaan komponen-komponen keras, perancangan alat juga membutuhkan software untuk menanam perintah dan instruksi untuk memfungsikan alat. Perangkat lunak atau software yang peneliti gunakan adalah Arduino 1.8.1. Aplikasi standar untuk Arduino ini sudah cukup untuk membantu dalam perancangan alat. Tampilan yang sederhana, kinerja yang baik dan ringan, serta adanya library sangat menunjang penelitian. Berbagai macam instruksi dan perintah yang dimasukkan atau ditulis ke dalam Arduino menggunakan aplikasi ini.

Pada bagian perancangan lunak ini yang dilakukan untuk menghasilkan listing program yang diinginkan sesuai dengan perancangan perangkat keras. Software Arduino dibuka dan masukkan script ke dalamnya, hal ini dapat dilihat pada gambar 4 berikut,

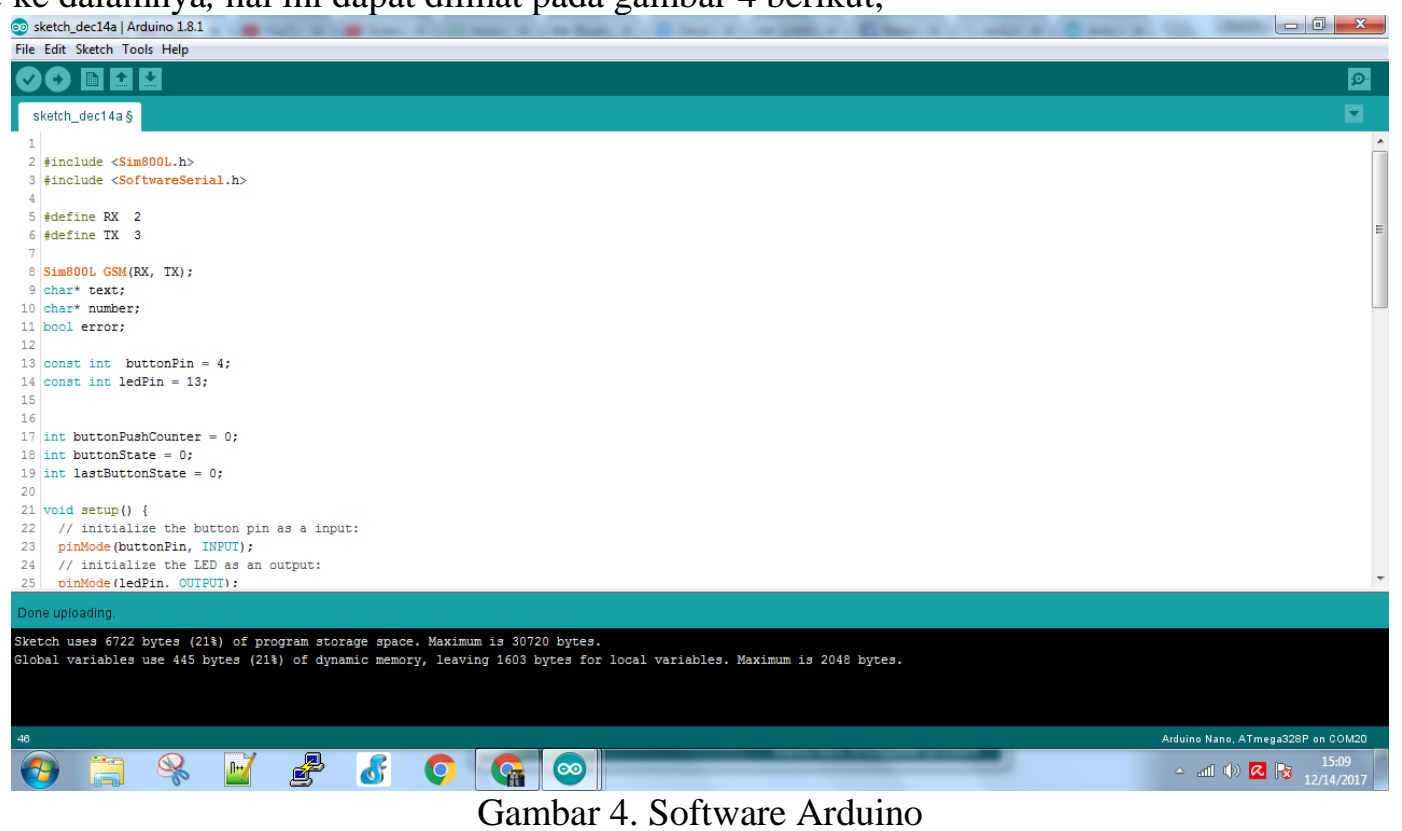

Setelah listing program ditulis semua, langkah selanjutnya proses kompilasi untuk mengecek apakah listing program yang ditulis terjadi kesalahan atau tidak, pilih menu verify, dapat dilihat pada gambar 4. Pada pemrograman ini perlu diperlihatkan untuk koneksi port-nya, karena pada pengalamatan port inilah mikrokontroler dapat berkomunikasi dengan PC atau laptop melalui komunikasi serial. Tabel 1 berikut ini adalah script secara keseluruhan yang dapat dimasukkan ke dalam software Arduino.

Tabel 1. Source Code Alarm Panic Button System

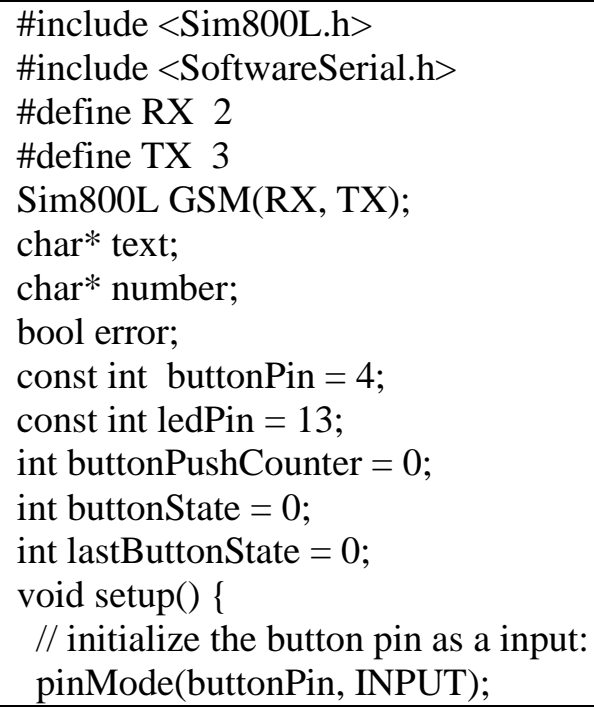




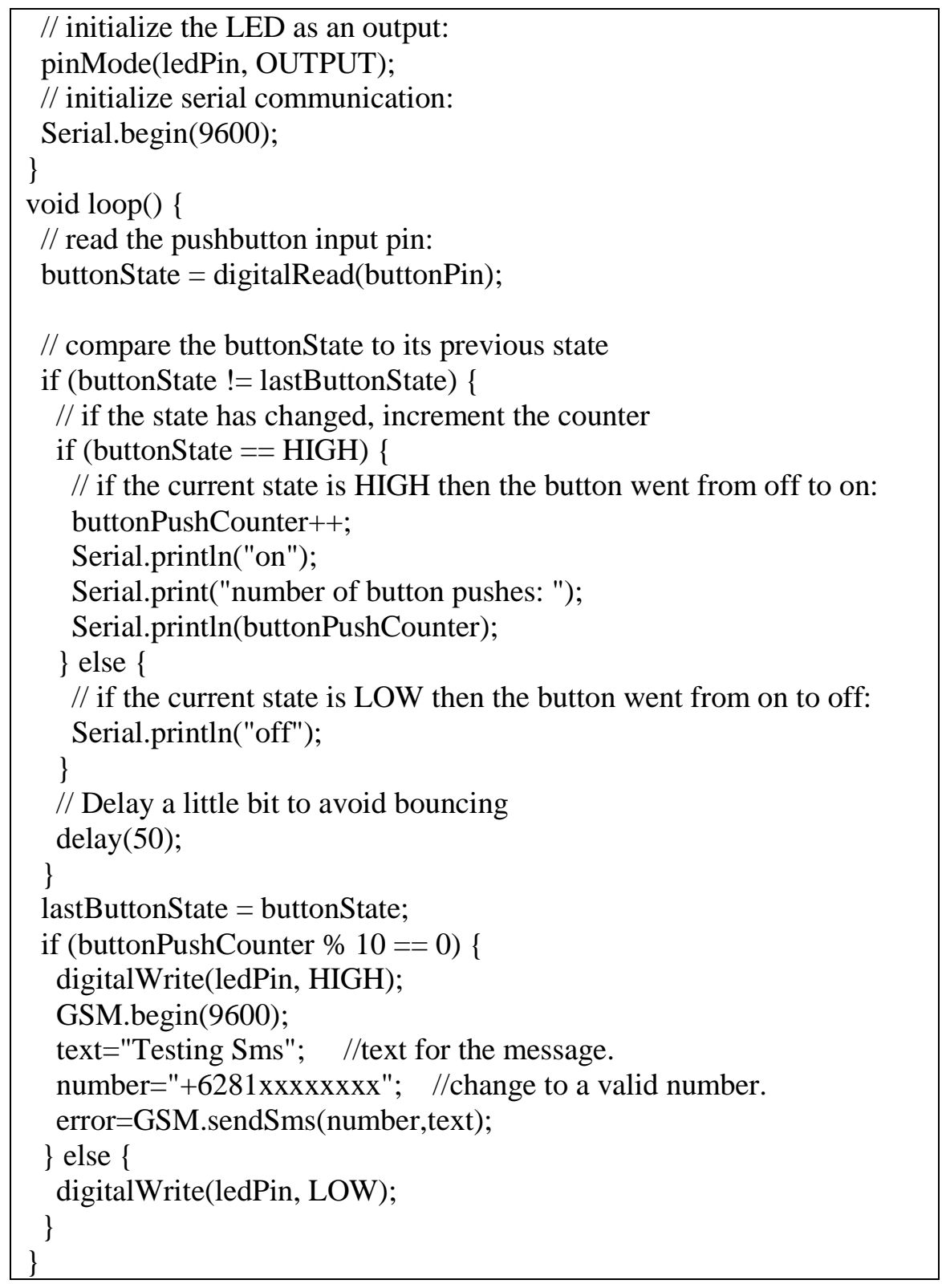

Tahapan terakhir setelah dimasukkan program ke dalam mikrokontroler, lalu klik menu Upload.

Gambar 5 berikut ini merupakan bentuk perancangan fisik prototipe Alarm Panic Button System. Rancangan ini terdapat keseluruhan rangkaian elektronika dan perangkat keras yang digunakan yang disusun secara rapi sesuai dengan fungsinya. 


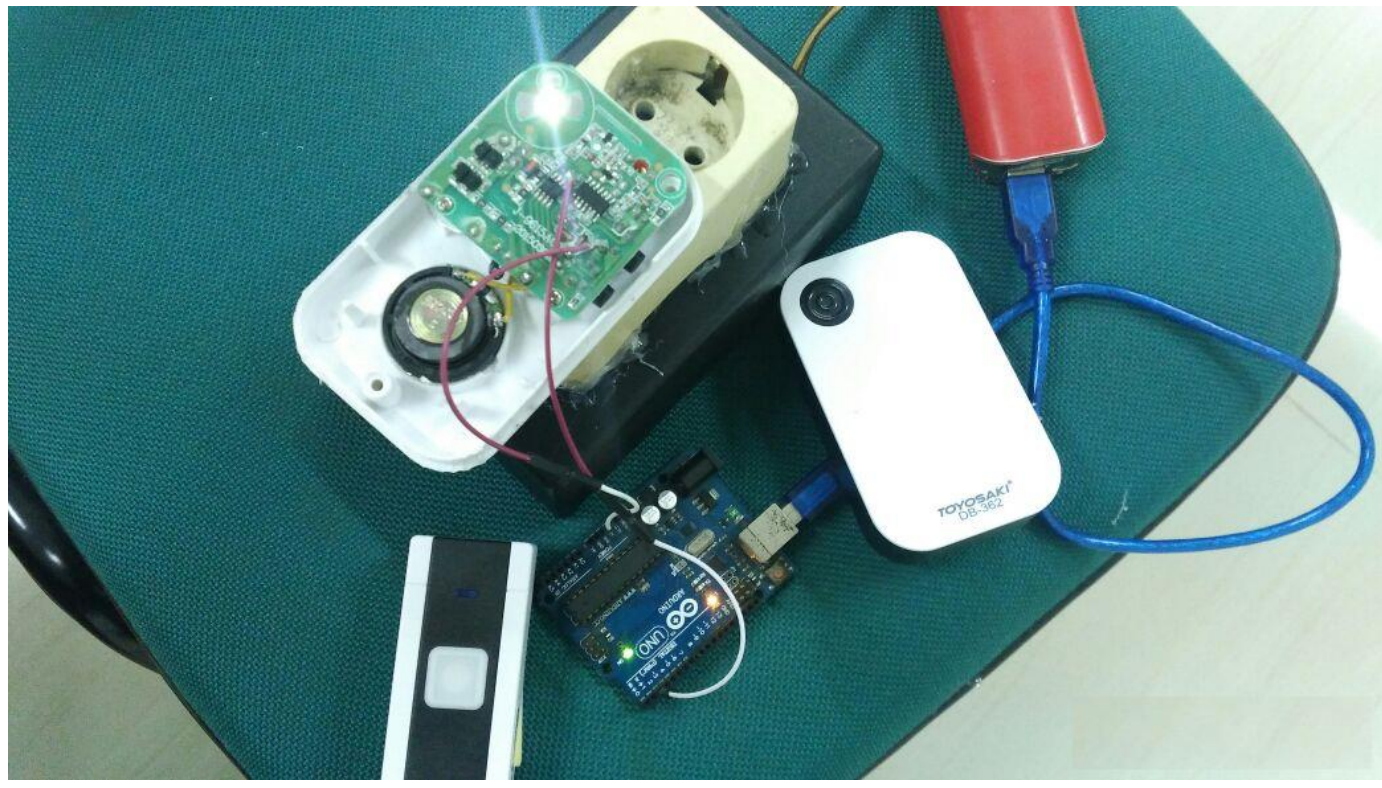

Gambar 5. Prototipe Alarm Panic Button System

Berdasarkan beberapa masalah yang ada, peneliti memberikan alternatif pemecahan masalah yaitu merancang sebuah alat pelayanan informasi publik untuk memudahkan masyarakat dalam mengatasi adanya tindak kejahatan, baik di lingkungan kerja ataupun sekitarnya. Selain mudah dioperasikan, alat ini dapat memberikan pelayanan yang lebih efektif, efesien dan diharapkan dapat berkontribusi dalam memecahkan masalah yang terjadi saat ini dalam pencegahan kriminalitas.

\section{KESIMPULAN}

Berdasarkan hasil analisa yang telah diuraikan dari pembahasan sebelumnya terdapat beberapa pokok penting yang dapat disimpulkan. Berikut ini hasil kesimpulan dari penelitian yang telah dilakukan, yaitu:

1. Proses pelayanan pengaduan informasi publik dengan sistem yang sudah berjalan saat ini di Polres Kota Tangerang masih kurang efektif dan efisien. Dimana ketika ada seorang yang ingin membutuhkan bantuan polisi dalam situasi mendesak atau sedang terjadinya tindak kejahatan seperti perampokan, pemohon hanya bisa menghubungi dengan telepon ke Sentral Pelayanan Kepolisian Terpadu (SPKT) Polres Kota Tangerang.

2. Perlu adanya inovasi dalam sistem pelayanan laporan masyarakat kepada Polres Kota Tangerang agar lebih efektif atau efesien. Proses penerima informasi yang akan memakan waktu, sehingga dapat terjadinya tindak kejahatan dan mempengaruhi dalam sistem pelayanan kepolisian yang kurang efektif.

3. Perancangan alat dimulai dengan membuat prototipe alat dengan rangkaian yang terdiri dari beberapa komponen. Kemudian alat dirakit menggunakan Arduino Uno yang dihubungkan dengan Modul SIM 800L GPRS GSM Micro Sim sebagai pusat rangkaian untuk mengirimkan pesan. Pesan tersebut akan dikirim langsung kepada Polres Kota Tangerang.

\section{SARAN}

Adapun saran pada alat ini masih terdapat beberapa kekurangan untuk dapat berjalan sesuai harapan. Bilamana ada pengembangan lebih lanjut terhadap alat ini maka perlu adanya perhatian untuk memperbaiki kekurangan tersebut seperti berikut,

1. Secara fungsional alat ini akan lebih mudah dimengerti bagi pemakainya dengan sebuah layar LED atau monitor yang memberikan informasi tentang area terkena dampak kejahatan.

2. Penambahan perangkat yang terhubung ke internet juga dibutuhkan agar publik juga bisa memantau aktivitas kinerja alat dari seluruh objek area pemasangan prototipe. 


\section{DAFTAR PUSTAKA}

[1] POLRI, 2017, Sentra Pelayanan Kepolisian Terpadu (SPKT), https://www.polri.go.id/pdf/Layanan\%20SPKT.pdf, diakses tanggal 27 Desember 2017.

[2] Ilamsyah, Setyawan, Hendri Iksan, Syahfitri, Alfianti, 2017, Robot Pencari Benda Menggunakan Perintah Suara Berbasis Arduino Uno, CERITA (Creative Education of Research In Information Technology and Artificial Informatics), No.2, Vol 3, 206-216.

[3] Shinde, P., Taware, P., Thorat, S., BE, Tejashree, Waghmare, 2012, Emergency Panic Button, IJSER (International Journal of Scientific \& Engineering Research), No.3, Vol.3, 1-3, https://www.ijser.org/researchpaper/Emergency-Panic-Button.pdf, diakses tanggal 14 Desember 2017.

[4] Majumdar, N., Bhargava, P., Shirin, R., K., 2014, Emergency Panic Button using Microcontrollers, IJCA (International Journal of Computer Applications), No.9, Vol.99, 1-3, http://citeseerx.ist.psu.edu/viewdoc/download?doi=10.1.1.679.70\&rep=repl\&type $=p d f$, diakses tanggal 10 Desember 2017.

[5] Awodele, O., Ernest, E., O., Olufunmike, A., O, Oluwawunmi, O., S., Anita, A., U, 2015, A Real-Time Crime Records Managements System For National Security Agencies, eJCSIT (European Journal of Computer Science and Information Technology), No.2, Vol 3, 1-12, http://www.eajournals.org/wp-content/uploads/A-Real-Time-Crime-Records-ManagementSystem-for-National-Security-Agencies.pdf, diakses tanggal 30 Desember 2017.

[6] Andrianto, Heri, Darmawan, Aan, 2016. Arduino Belajar Cepat dan Pemrograman, Informatika, Bandung. 